\title{
Kajian Kualitas Air dan Laju Sedimentasi Pada Saluran Irigasi Bendung Tanah Abang di Kecamatan Long Mesangat Kabupaten Kutai Timur
}

\author{
Amprin 1, Abdunnur'2, dan Muh. Amir Masruhim ${ }^{3}$ \\ ${ }^{1}$ Sekolah Tinggi Pertanian Kutai Timur, Jl. Soekarno-Hatta No. 1, Sangatta, Kutai Timur, \\ Kalimantan Timur \\ 2,3 Pusat Unggulan Studi Tropis, Universitas Mulawarman, JI Kuaro Samarinda, Kalimantan Timur \\ ${ }^{1}$ Email: salam_amrin79@yahoo.co.id
}

\begin{abstract}
The aim of this research is to know the water quality on physics, chemistry, and biology parameter and also sedimentation rate on irrigation canal at Long Mesangat district. The analysis of water quality on physics, chemistry, and biology by using storet index. While, the sedimentation rate by using the water debit at irrigation canal, and total suspended solid (TSS) matter. The result of this research showed that the water quality of irrigation canal was qualified of standard quality of III and IV levels that allocated for fishery cultivation and farming. Water quality was qualified of standards for Class I, II, III and IV, physical parameters with an average temperature of $31.7^{\circ} \mathrm{C}$, TDS: $0.016 \mathrm{mg} / \mathrm{L}$, TSS: $19.61 \mathrm{mg} / \mathrm{L}$, and Turbidity: $62.76 \mathrm{NTU}$. While the chemical parameters were an average BOD-5 $1.2 \mathrm{mg} / \mathrm{L}$, NO $38.22 \mathrm{mg} / \mathrm{L}$, Nitrite $0.023 \mathrm{mg} / \mathrm{L}$, and Sulphate $29.43 \mathrm{mg} / \mathrm{L}$. Chemical parameters that was not qualified of standards for Class I and II were averages Fe levels of $0.94 \mathrm{mg} / \mathrm{L}, \mathrm{Cl}$ levels of $3.91 \mathrm{mg} / \mathrm{L}$, COD levels of $25.03 \mathrm{mg} / \mathrm{L}$, and DO $4.85 \mathrm{mg} / \mathrm{L}$. Biological parameter coliform total was not qualified (primary canal : 513.33/100 ml, Secondary canal : $670 / 100 \mathrm{ml}$, tertiary canal : $1126.67 / 100 \mathrm{ml}$ ). The sedimentation rate at irrigation canal continued were 0.724 ton/day, 0.451 ton/day and 0.021 ton/day.
\end{abstract}

Keyword : Dyke, Irrigation canal, Sedimentation speed, TSS, Water quality

\begin{abstract}
ABSTRAK
Penelitian ini bertujuan untuk mengetahui kualitas air secara fisika, kimia dan biologi serta laju sedimentasi pada Saluran Irigasi di Kecamatan Long Mesangat. Analisis kualitas air secara fisika, kimia dan biologi dengan menggunakan Indeks Storet. Sedangkan laju sedimentasi dengan menghitung debit air saluran irigasi, dan total padatan tersuspensi (TSS). Hasil penelitian menunjukan bahwa kualitas air pada saluran irigasi adalah memenuhi standar baku mutu kelas III dan IV yang peruntukannya budidaya perikanan dan pertanian. Kualitas air memenuhi standar baku mutu untuk Kelas I, II, III dan IV yaitu Parameter fisika dengan rata-rata suhu $31,7^{\circ} \mathrm{C}$, TDS : $0,016 \mathrm{mg} / \mathrm{L}$, TSS : $19,61 \mathrm{mg} / \mathrm{L}$, dan Kekeruhan : 62,76 NTU. Sedangkan parameter kimia adalah memiliki rerata BOD-5 1,2 mg/L, $\mathrm{NO}_{3} \quad 8,22$ $\mathrm{mg} / \mathrm{L}$, Nitrit 0,023 $\mathrm{mg} / \mathrm{L}$, dan Sulfat $29,43 \mathrm{mg} / \mathrm{L}$ ). Parameter kimia yang tidak memenuhi standar baku mutu untuk Kelas I dan II adalah rerata kadar Fe 0,94 mg/L, kadar $\mathrm{Cl} 3,91 \mathrm{mg} / \mathrm{L}$, kadar COD 25,03 mg/L, dan DO 4,85 mg/L. Parameter biologi total coliform tidak memenuhi ( S.Primer : $513,33 / 100 \mathrm{ml}$, S.Sekunder : $670 / 100 \mathrm{ml}$, S.Tersier : 1126,67/100ml). Laju sedimentasi pada saluran irigasi berturut-turut adalah 0,724 ton/hari, 0,451 ton/hari dan 0,021 ton/hari.
\end{abstract}

Kata kunci: Bendungan, Kualitas Air, Laju Sedimentasi, Saluran Irigasi, TSS

\section{Pendahuluan}

Air sebagai sumber daya alam yang ketersediannya mutlak diperlukan sepanjang masa baik untuk keperluan manusia sendiri maupun makhluk hidup lainnya seperti hewan dan tumbuh-tumbuhan. Pemanfaatan air pada sektor pertanian adalah sebagai air irigasi. Air irigasi merupakan air yang penting untuk mendukung pertumbuhan dan produksi tanaman padi. 
Kecamatan Long Mesangat, Kabupaten Kutai Timur merupakan salah satu kecamatan yang dikembangkan sebagai lumbung padi. Pembangunan bendungan dan saluran irigasi telah dilaksanakan untuk mendukung suksesnya program pemerintah tersebut. Pencetakan sawah baru dan saluran irigasi juga terus dilaksanakan. Bendung Tanah Abang terletak di Desa Tanah Abang Kecamatan Long Mesangat yang secara geografis terletak pada $00^{\circ} 35^{\prime \prime}-61$ " LU dan $116^{\circ} 43^{\prime \prime}-51,3$ " BT dengan elevasi 51 meter dari permukaan laut (dpl). Bendung tanah Abang memiliki kemampuan mengairi lahan sawah seluas 2.365 ha. Sumber utama air Bendung Tanah Abang berasal dari Sungai Long Mesangat.

Kondisi fisik bangunan Bendung Tanah Abang Kecamatan Long Mesangat dan saluran irigasinya pada saat ini masih tergolong baik. Bendung Tanah Abang memiliki saluran irigasi yang terdiri dari saluran primer sepanjang $2.500 \mathrm{~m}$, saluran sekunder sepanjang $12.000 \mathrm{~m}$ dan saluran tersier sepanjang $3.800 \mathrm{~m}$ (Kementrian Dalam Negeri, 2015).

Berdasarkan Peraturan Pemerintah Nomor 20 tahun 2006, irigasi adalah usaha penyediaan, pengaturan, dan pembuangan air irigasi untuk menunjang pertanian yang sejenisnya meliputi irigasi permukaan, irigasi rawa, irigasi air bawah tanah, irigasi pompa dan irigasi tambak. Kualitas air irigasi sangat berpengaruh terhadap produksi padi di lahan sawah. Penurunan kualitas akan berdampak pada produksi padi dan meningkatkan biaya usaha tani tersebut. Selain itu kuantitas dan kontinyuitas ketersediaan air untuk irigasi juga berpengaruh terhadap luasan lahan pencetakan sawah. Adanya pembukaan lahan untuk aktifitas tambang dan perkebunan diperkirakan akan menyebabkan penurunan kualitas air dan meningkatnya sedimentasi pada saluran irigasi dan Bendungan Tanah Abang. Pengelolaan DAS dan penerapan tata guna lahan yang tidak dilakukan dengan baik dapat mempengaruhi terjadinya erosi dan sedimentasi. Erosi dapat mempengaruhi produktivitas lahan yang biasanya mendominasi pada DAS bagian hulu dan berdampak negatif pada bagian hilir yang berupa hasil sedimen.

Perubahan kualitas dan kuantitas air irigasi perlu diketahui untuk menyusun perencanaan tata guna lahan dan mengetahui kondisi lingkungan sekitar daerah aliran sungai (DAS). Dengan adanya pemantauan kualitas dan kuantitas air secara berkala dapat memberikan informasi bagi pemerintah dan masyarakat. Oleh karena itu pemantauan awal kualitas dan kuantitas air sangat perlu dilakukan untuk mengetahui kondisi air irigasi di Kecamatan Long Mesangat, Kabupaten Kutai Timur baik secara kualitas maupun kuantitas. Penelitian ini mempunyai tujuan yaitu 1). Mengetahui kualitas air secara fisika, kimia dan biologi pada saluran irigasi. 2). Mengetahui laju sedimentasi pada saluran primer, sekunder dan tersier. 


\section{Metode Penelitian}

Data dalam penelitian ini meliputi data primer dan data sekunder, sedangkan sifat data yang dipakai dalam penelitian ini adalah kualitatif dan kuantitatif. Data primer, yaitu jenis data yang dikumpulkan secara langsung di lapangan dan berasal dari narasumber yang diperlukan yaitu masyarakat yang menggunakan irigasi, pengelola kawasan, pejabat yang berkompeten, tokoh masyarakat dan unsur masyarakat khususnya yang berdomisili disekitar kawasan irgasi. Pengambilan contoh air dilakukan dengan metode purposive sampling yaitu tiap saluran diambil 3 titik (hulu, tengah dan hilir) dengan 2 kali pengambilan sampel. Pada titik pengamatan tersebut diambil contoh air irigasi untuk pengukuran kualitas air dan sedimentasi. Pada titik tersebut diuji kualitas secara in situ yang meliputi, pH, Temperatur, Total Disolved Solid (TDS), dan Debit air. Pada titik pengamatan juga diambil contoh air untuk uji laboratorium meliputi kualitas secara fisika, kimia, dan biologi. Data sekunder, jenis data yang diperoleh dari hasil survey yang dilakukan ke beberapa instansi yang berkaitan dengan kepentingan penelitian ini. Data sekunder bisa berupa dokumen pemerintah, makalah, jurnal dan hasil penelitian yang pernah dilakukan pihak lain.

\section{Teknik Analisis Data}

Pengolahan data mencakup kegiatan penyuntingan data dan informasi yang dikumpulkan melalui data uji laboratorium dan sekunder, input data/informasi, validasi data, input data hasil validasi sesuai dengan variabel yang akan dianalisis.

Tahapan analisis data terbagi menjadi 3, yaitu sebagai berikut :

a. Gambaran umum Kecamatan Long Mesangat tentang pemanfaatan lahan, kependudukan, rencana tata ruang wilayah, data curah hujan dan topografi.

b. Analisis Kualitas Air

Analisis kualitas air dilakukan untuk mendapatkan gambaran kualitas air secara fisika, kimia dan biologi serta untuk mengetahui peruntukan dari air tersebut menggunakan indeks Storet berdasarkan pp no 82 tahun 2001 tentang pengelolaan kualitas air dan pengendalian pencemaran air.

c. Laju Sedimentasi

Analisis ini diperlukan untuk mengetahui kecepatan pengendapan material-material sedimen akibat dari adanya erosi yang masuk dalam daerah aliran sungai.

Analisa data yang digunakan meliputi :

\section{Analisa Debit Air}

Debit adalah suatu koefisien yang menyatakan banyaknya air yang mengalir dari suatu sumber persatu-satuan waktu, biasanya diukur dalam satuan $\mathrm{m}^{3}$ per detik. Rumus yang digunakan :

$$
Q_{w} \quad=A \times V
$$

Keterangan : 


$$
\begin{array}{ll}
Q_{w} & =\text { debit air }\left(\mathrm{m}^{3} / \text { det }\right) \\
\text { A } & =\text { luas penampang saluran }\left(\mathrm{m}^{2}\right) \\
V & =\text { kecepatan aliran }(\mathrm{m} / \text { det })
\end{array}
$$

\section{Laju Sedimen}

Berdasarkan angkutan sedimen yang terjadi maka laju sedimen layang dihitung dengan rumus :

$$
\text { Qs }=0,0864 C Q_{w}
$$

Dimana:

$$
\begin{array}{ll}
\text { Qs } & =\text { laju sedimen (ton/hari) } \\
\text { C } & =\text { Konsentrasi sedimen }(\mathrm{mg} / \mathrm{l}) \\
\text { Qw } & =\text { Debit sungai }(\mathrm{m} 3 / \text { detik) } \\
0.0864 & =\text { Konversi satuan }
\end{array}
$$

\section{Kualitas Air}

Uji kualitas air dilakukan dengan mengambil sampel di beberapa titik pada bendung dan saluran irigasi. Sampel yang di peroleh kemudian di analisis pada Laboratorium Kualitas Air Fakultas Perikanan dan IImu Kelautan Universitas Mulawarman untuk analisa kimia dan biologi. Sedangkan analisa fisika dilakukan pengukuran parameter air secara insitu meliputi $\mathrm{pH}$, Temperatur, dan TDS.

Data yang diperoleh dari hasil pemeriksaan kualitas air kemudian dibandingkan dengan tabel klasifikasi nilai standar baku mutu kelas air PP No 82 tahun 2001. Perhitungan status kualitas air digunakan Metode Storet, dengan penentuan status kualitas air adalah dengan menggunakan sistem nilai US-EPA (United Status Environment Protection Agency) dengan mengklasifikasikan kualitas air dalam empat kelas, yaitu:

1. Kelas $A$ : baik sekali, skor $=0$ (memenuhi baku kualitas),

2. Kelas $B$ : baik, skor $=-1$ s.d -10 (cemar ringan),

3. Kelas $C$ : sedang, skor $=-11$ s.d -30 (cemar sedang),

4. Kelas $D:$ buruk, skor $=-31$ (cemar berat),

Tabel 1. Kriteria Mutu Air Berdasarkan Kelas Menurut PP No 82 Tahun 2001

\begin{tabular}{clccccc}
\hline \multirow{2}{*}{ NO } & \multirow{2}{*}{ PARAMETER } & \multirow{2}{*}{ SATUAN } & \multicolumn{5}{c}{ Kelas } \\
\cline { 5 - 7 } I & FISIKA & & I & II & III & IV \\
$\mathbf{1}$ & Temperatur & oC & $\operatorname{dev} 3$ & $\operatorname{dev} 3$ & $\operatorname{dev} 3$ & $\operatorname{dev} 5$ \\
$\mathbf{2}$ & TDS & $\mathrm{mg} / \mathrm{L}$ & 1000 & 1000 & 1000 & 2000 \\
$\mathbf{3}$ & TSS & $\mathrm{mg} / \mathrm{L}$ & 50 & 50 & 400 & 400 \\
$\mathbf{4}$ & Kekeruhan & $\mathrm{NTU}$ & & & & \\
II & KIMIA & & & & & \\
$\mathbf{1}$ & $\mathrm{pH}$ & - & $6-9$ & $6-9$ & $6-9$ & $5-9$ \\
$\mathbf{2}$ & BOD-5 & $\mathrm{mg} / \mathrm{L}$ & 2 & 3 & 6 & 12 \\
$\mathbf{3}$ & COD & $\mathrm{mg} / \mathrm{L}$ & 10 & 25 & 50 & 100 \\
$\mathbf{4}$ & DO & $\mathrm{mg} / \mathrm{L}$ & 6 & 4 & 3 & 0 \\
$\mathbf{5}$ & NO3 & $\mathrm{mg} / \mathrm{L}$ & 10 & 10 & 20 & 20 \\
$\mathbf{6}$ & Nitrit & $\mathrm{mg} / \mathrm{L}$ & 0,06 & 0,06 & 0,06 & $(-)$ \\
$\mathbf{7}$ & Sulfat & $\mathrm{mg} / \mathrm{L}$ & 400 & $(-)$ & $(-)$ & $(-)$ \\
$\mathbf{8}$ & Besi & $\mathrm{mg} / \mathrm{L}$ & 0,3 & $(-)$ & $(-)$ & $(-)$ \\
$\mathbf{9}$ & Klorida & $\mathrm{mg} / \mathrm{L}$ & 1 & $(-)$ & $(-)$ & $(-)$ \\
III & BIOLOGI & & & & & \\
$\mathbf{1}$ & Total Coliform & $\mathrm{Jml} / \mathbf{1 0 0} \mathrm{ml}$ & 1000 & 5000 & 10000 & 10000 \\
\hline
\end{tabular}


Hasil pengukuran semua parameter kualitas air dibandingkan dengan baku mutu nilai kualitas air, jika hasil pengukuran memenuhi nilai standar baku mutu kualitas air (hasil pengukuran < dari baku mutu maka diberi skor 0 . Jika hasil pengukuran tidak memenuhi standar baku mutu kualitas air (hasil pengukuran > baku kualitas), maka diberi skor sesuai Tabel 2.

Tabel 2. Penentuan Sistem Nilai Metode storet untuk menentukan Status Kualitas Air

\begin{tabular}{|c|c|c|c|c|}
\hline \multirow{2}{*}{ Jumlah contoh ${ }^{-1}$ ) } & \multirow{2}{*}{ Nilai } & \multicolumn{3}{|c|}{ Parameter } \\
\hline & & Fisika & Kimia & Biologi \\
\hline \multirow[t]{3}{*}{$<10$} & Maksimum & -1 & -2 & -3 \\
\hline & Minimum & -1 & -2 & -3 \\
\hline & Rata-rata & -3 & -6 & -9 \\
\hline \multirow[t]{3}{*}{$\geq 10$} & Maksimum & -2 & -4 & -6 \\
\hline & Minimum & -2 & -4 & -6 \\
\hline & Rata-rata & $-\overline{6}$ & -12 & -18 \\
\hline \\
\hline \multirow{2}{*}{\multicolumn{5}{|c|}{$\begin{array}{l}\text { Keterangan: } \\
\text { 1) : Jumlah parameter yang digunakan untuk penentuan statu } \\
\text { kualitas air }\end{array}$}} \\
\hline & & & & \\
\hline \multicolumn{5}{|c|}{$\begin{array}{l}\text { : Jumlah negatif dari seluruh parameter dihitung dan ditentukar } \\
\text { status kualitasnya dan jumlah skor yang didapat dengar } \\
\text { menggunakan sistem nilai tersebut di atas }\end{array}$} \\
\hline
\end{tabular}

\section{Hasil dan Pembahasan}

\section{Saluran Primer}

Pada musim kemarau yang cukup panjang tahun 2016 ini debit sungai mulai menurun dan berdampak pada masyarakat terutama petani. Hasil pengamatan kualitas air pada saluran primer pada Bendung Tanah Abang, Kecamatan Long Mesangat disajikan pada Tabel 3.

Tabel 3. Nilai Kualitas Air Pada Saluran Primer di Kecamatan Long Mesangat

\begin{tabular}{|c|c|c|c|c|c|c|c|c|c|c|c|}
\hline & \multirow{2}{*}{ Parameter } & \multirow{2}{*}{ Satuan } & \multicolumn{6}{|c|}{ Sampel } & \multirow{2}{*}{ Min } & \multirow{2}{*}{ Max } & \multirow{2}{*}{ Rerata } \\
\hline & & & 1 & 2 & 3 & 4 & 5 & 6 & & & \\
\hline 1 & Temperatur & ${ }^{\circ} \mathrm{C}$ & 29,2 & 29,1 & 29,7 & 29,6 & 30,6 & 30,6 & 29,1 & 30,6 & 29,8 \\
\hline 2 & TDS & $\mathrm{mg} / \mathrm{L}$ & 0,019 & 0,019 & 0,017 & 0,017 & 0,014 & 0,014 & 0,014 & 0,019 & 0,017 \\
\hline 3 & TSS & $\mathrm{mg} / \mathrm{L}$ & 32,00 & 16,00 & 21,00 & 34,00 & 5,00 & 25,00 & 5 & 34 & 22,17 \\
\hline 4 & Kekeruhan & NTU & 56,00 & 60,00 & 80,00 & 77,00 & 60,00 & 65,00 & 56 & 80 & 66,33 \\
\hline 5 & $\mathrm{pH}$ & & 7,20 & 7,15 & 6,80 & 6,82 & 6,70 & 6,71 & 6,7 & 7,2 & 6,90 \\
\hline 6 & BOD-5 & $\mathrm{mg} / \mathrm{L}$ & 1,25 & 1,15 & 1,20 & 1,22 & 1,18 & 1,12 & 1,12 & 1,25 & 1,19 \\
\hline 7 & COD & $\mathrm{mg} / \mathrm{L}$ & 24,69 & 46,36 & 21,08 & 15,06 & 7,84 & 9,04 & 7,84 & 46,36 & 20,68 \\
\hline 8 & DO & $\mathrm{mg} / \mathrm{L}$ & 3,80 & 4,47 & 4,57 & 4,94 & 5,36 & 3,52 & 3,52 & 5,36 & 4,44 \\
\hline 9 & NO3 & $\mathrm{mg} / \mathrm{L}$ & 7,66 & 7,58 & 7,89 & 9,01 & 8,20 & 8,98 & 7,58 & 9,01 & 8,22 \\
\hline 10 & Nitrit & $\mathrm{mg} / \mathrm{L}$ & 0,02 & 0,02 & 0,03 & 0,03 & 0,02 & 0,02 & 0,02 & 0,03 & 0,02 \\
\hline 11 & Sulfat & $\mathrm{mg} / \mathrm{L}$ & 16,41 & 28,30 & 15,65 & 29,37 & 22,66 & 34,86 & 15,65 & 34,86 & 24,54 \\
\hline 12 & Besi & $\mathrm{mg} / \mathrm{L}$ & 0,91 & 1,22 & 0,98 & 1,06 & 0,98 & 0,91 & 0,098 & 1,22 & 0,86 \\
\hline 13 & Klorida & $\mathrm{mg} / \mathrm{L}$ & 3,91 & 3,91 & 3,91 & 3,91 & 3,91 & 3,91 & 3,91 & 3,91 & 3,91 \\
\hline 14 & $\begin{array}{l}\text { Total } \\
\text { Coliform }\end{array}$ & $\begin{array}{c}\mathrm{Jml} / 100 \\
\mathrm{ml}\end{array}$ & 440 & 270 & 390 & 1500 & 240 & 240 & 240 & 1500 & 513,33 \\
\hline
\end{tabular}

Kondisi air saluran primer terdapat paramater yang melebihi ambang batas yang diperkenankan yaitu untuk baku mutu Kelas I, dan Kelas II. Hasil perhitungan indeks storet disajikan pada Tabel 4. 
Tabel 4. Hasil Perhitungan Indeks Storet berdasarkan PP No 82 tahun 2001 pada Saluran Primer

\begin{tabular}{cccc}
\multicolumn{2}{c}{ di Kecamatan Long Mesangat } & & \\
\hline NO & BAKU MUTU & SALURAN PRIMER & KETERANGAN \\
\hline 1 & Kelas I & -40 & Tercemar Berat \\
2 & Kelas II & -4 & Tercemar Ringan \\
3 & Kelas III & 0 & Memenuhi \\
4 & Kelas IV & 0 & Memenuhi \\
\hline
\end{tabular}

Total nilai Negatif untuk kelas I adalah -40 yang terdiri dari parameter kimia dan Biologi. Parameter kimia adalah COD pada nilai maksimum dan rata-rata (-8), DO pada nilai minimum, maksimum dan rata-rata $(-10)$, Besi pada nilai minimum, maksimum dan rata-rata (-9) dan Klorida pada nilai minimum, maksimum dan rata-rata (-10). Parameter biologi yaitu total colliform melebihi batas ambang pada nilai maksimum (-3). Perhitungan indeks Storet untuk kelas II, saluran primer Bendung Tanah Abang tidak memenuhi baku mutu kelas II dengan pencemaran ringan dengan total nilai negatif adalah -4. Parameterparameter yang tidak memenuhi adalah parameter kimia yaitu COD pada nilai maksimum (-2), DO pada nilai minimum (-2). Sedangkan untuk kelas III dan IV memenuhi baku mutu.

Kandungan besi yang melebihi ambang batas menyebabkan kebutuhan oksigen untuk mengurai bahan kimia (COD) juga meningkat. Hal tersebut mengakibatkan oksigen terlarut dalam air (DO) juga berkurang. Besi terlarut dalam air dapat berbentuk kation ferro $\left(\mathrm{Fe}^{2+}\right)$ atau kation ferri $\left(\mathrm{Fe}^{3+}\right)$. Hal ini tergantung kondisi $\mathrm{pH}$ dan oksigen terlarut dalam air. Besi terlarut dapat berbentuk senyawa tersuspensi, sebagai butir koloidal seperti $\mathrm{Fe}(\mathrm{OH})_{3}$, $\mathrm{FeO}, \mathrm{Fe}_{2} \mathrm{O}_{3}$ dan lain-lain (Effendi, 2003).

Pada saluran primer parameter TDS memiliki nilai yang rendah, deikian juga nilai $\mathrm{pH}$-nya. Kedua parameter ini saling terkait dengan daya hantar listrik. Semakin rendah nilai tds maka nilai daya hantar listrik juga rendah ditambah dengan $\mathrm{pH}$ air yang cenderung netral. Nilai parameter TDS sangat mempengaruhi tekstur, permeabilitas dan kesuburan tanah pada irigasi pertanian (Astuti, 2014).

Pencemaran air juga dipengaruhi penggunaan pestisida pada areal sawah dan dapat memasuki badan air. Limpasan permukaan dan erosi, pencucian dan drainase merupakan jalur utama masuknya polusi. Pestisida yang tertinggi mempengaruhi pencemaran air adalah golongan organoklorin, strobin, dan organofospat (Vymazal, dan Březinová, 2015).

\section{Saluran Sekunder}

Saluran Sekunder memiliki kualitas yang tidak jauh berbeda dengan saluran primer. Hasil pengamatan kualitas air pada saluran sekunder pada Bendung Tanah Abang, Kecamatan Long Mesangat disajikan pada Tabel 5. Saluran sekunder memiliki nilai negatif untuk kelas I sebesar -43 termasuk pada pencemaran berat. Paramater yang tidak memenuhi baku mutu baku mutu Kelas I, adalah COD pada nilai minimum, maksimum dan rata-rata $(-10)$, DO pada nilai minimum, maksimum dan rata-rata $(-10)$, Besi pada nilai 
minimum, maksimum dan rata-rata $(-10)$ dan Klorida pada nilai minimum, maksimum dan rata-rata $(-10)$. Parameter biologi yaitu total e-colli melebihi batas ambang pada nilai maksimum (-3).

Tabel 5. Nilai Kualitas Air Pada Saluran Sekunder di Kecamatan Long Mesangat

\begin{tabular}{|c|c|c|c|c|c|c|c|c|c|c|c|}
\hline \multirow{2}{*}{ No } & \multirow{2}{*}{ Parameter } & \multirow{2}{*}{ Satuan } & \multicolumn{6}{|c|}{ Sampel } & \multirow{2}{*}{ Min } & \multirow[b]{2}{*}{ Max } & \multirow[b]{2}{*}{ Rerata } \\
\hline & & & 1 & 2 & 3 & 4 & 5 & 6 & & & \\
\hline 1 & Temperatur & ${ }^{\circ} \mathrm{C}$ & 32 & 33,1 & 34,2 & 33,5 & 31,6 & 31,2 & 31,2 & 34,2 & 32,6 \\
\hline 2 & TDS & $\mathrm{mg} / \mathrm{L}$ & 0,015 & 0,015 & 0,012 & 0,012 & 0,016 & 0,016 & 0,012 & 0,016 & 0,0143 \\
\hline 3 & TSS & $\mathrm{mg} / \mathrm{L}$ & 9 & 31 & 18 & 14 & 2 & 24 & 2 & 31 & 16,33 \\
\hline 4 & Kekeruhan & NTU & 62 & 65 & 60 & 66 & 52 & 60 & 52 & 66 & 60,8 \\
\hline 5 & $\mathrm{pH}$ & & 6,6 & 6,5 & 6,7 & 6,8 & 6,6 & 6,6 & 6,5 & 6,8 & 6,6 \\
\hline 6 & BOD-5 & $\mathrm{mg} / \mathrm{L}$ & 1,25 & 1,19 & 1,20 & 1,22 & 1,25 & 1,22 & 1,19 & 1,25 & 1,2 \\
\hline 7 & COD & $\mathrm{mg} / \mathrm{L}$ & 16,29 & 29,51 & 24,69 & 21,08 & 52,38 & 40,34 & 16,29 & 52,38 & 30,72 \\
\hline 8 & DO & $\mathrm{mg} / \mathrm{L}$ & 4,73 & 4,52 & 4,48 & 4,45 & 5,29 & 4,36 & 4,36 & 5,29 & 4,64 \\
\hline 9 & NO3 & $\mathrm{mg} / \mathrm{L}$ & 7,91 & 8,80 & 7,39 & 8,22 & 9,23 & 8,27 & 7,39 & 9,23 & 8,30 \\
\hline 10 & Nitrit & $\mathrm{mg} / \mathrm{L}$ & 0,02 & 0,02 & 0,02 & 0,02 & 0,02 & 0,02 & 0,02 & 0,02 & 0,02 \\
\hline 11 & Sulfat & $\mathrm{mg} / \mathrm{L}$ & 42,33 & 30,59 & 30,59 & 23,88 & 33,18 & 44,47 & 23,88 & 44,47 & 34,17 \\
\hline 12 & Besi & $\mathrm{mg} / \mathrm{L}$ & 1,16 & 0,94 & 0,95 & 1,01 & 0,82 & 0,91 & 0,82 & 1,16 & 0,97 \\
\hline 13 & Klorida & $\mathrm{mg} / \mathrm{L}$ & 3,91 & 3,91 & 3,91 & 3,91 & 3,91 & 3,91 & 3,91 & 3,91 & 3,91 \\
\hline 14 & $\begin{array}{l}\text { Total } \\
\text { Coliform }\end{array}$ & $\begin{array}{c}\mathrm{Jml} / 100 \\
\mathrm{ml}\end{array}$ & 390 & 230 & 260 & 1200 & 740 & 1200 & 230 & 1200 & 670 \\
\hline
\end{tabular}

Sumber : data Primer 2016

Tabel 6. Hasil Perhitungan Indeks Storet berdasarkan PP No 82 tahun 2001 pada saluran Sekunder di Kecamatan Long Mesangat

\begin{tabular}{cccc}
\hline NO & BAKU MUTU & $\begin{array}{c}\text { SALURAN } \\
\text { SEKUNDER }\end{array}$ & KETERANGAN \\
\hline 1 & Kelas I & -43 & Tercemar Berat \\
2 & Kelas II & -8 & Tercemar Ringan \\
3 & Kelas III & 0 & Memenuhi \\
4 & Kelas IV & 0 & Memenuhi \\
\hline
\end{tabular}

Perhitungan indeks Storet untuk kelas II, saluran sekunder bendung tanah abang tidak memenuhi baku mutu kelas II dengan pencemaran ringan. Parameter yang tidak memenuhi adalah COD pada nilai maksimum dan rata-rata (-8). Sedangkan untuk kelas III dan IV memenuhi baku mutu. Dissolved Oxygen atau oksigen terlarut pada saluran sekunder oksigen terlarutnya sebesar 4,64 mg/L memenuhi baku mutu kelas II sedangkan kelas I tidak memenuhi. Jumlah oksigen terlarut dipengaruhi oleh suhu, tekanan atmosfer dan fotosintesis tanaman air. Pada saluran irigasi adanya pintu air dan pintu sadap dapat mempengaruhi jumlah oksigen terlarut. Aerasi alami dapat terjadi pada pintu-pintu air yang dipengaruhi oleh kemiringan, kecepatan aliran air, dan kekasaran. Menurut Azmi, dkk., (2015), faktor lain yang mempengaruhi aerasi alami adalah profil penampang, lebar penampang, panjang penampang, kedalaman muka air, dan klimatologi.

Menurut Atima (2015), Nilai BOD dan COD memiliki peranan penting untuk mengetahui kualitas air dimana apabila nilai BOD rendah atau masih memenuhi baku mutu maka perairan tersebut terkandung bahan beracun atau telah tercemar. Dan sebaliknya apabila nilainya cukup tinggi atau melebihi baku mutu maka terindikasi tercemar dengan bahan organik. 


\section{Saluran Tersier}

Hasil pengamatan kualitas air pada saluran tersier pada Bendung Tanah Abang, Kecamatan Long Mesangat disajikan pada Tabel 7.

Tabel 7. Nilai Kualitas Air Pada Saluran Tersier di Kecamatan Long Mesangat

\begin{tabular}{|c|c|c|c|c|c|c|c|c|c|c|c|}
\hline \multirow{2}{*}{ No } & \multirow{2}{*}{ Parameter } & \multirow{2}{*}{ Satuan } & \multicolumn{6}{|c|}{ Sampel } & \multirow{2}{*}{ Min } & \multirow{2}{*}{ Max } & \multirow{2}{*}{ Rerata } \\
\hline & & & 1 & 2 & 3 & 4 & 5 & 6 & & & \\
\hline 1 & Temperatur & ${ }^{\circ} \mathrm{C}$ & 31,9 & 32 & 34,2 & 34 & 32 & 32,1 & 31,9 & 34,2 & 32,7 \\
\hline 2 & TDS & $\mathrm{mg} / \mathrm{L}$ & 0,017 & 0,018 & 0,016 & 0,015 & 0,019 & 0,019 & 0,015 & 0,019 & 0,017 \\
\hline 3 & TSS & $\mathrm{mg} / \mathrm{L}$ & 18 & 20 & 30 & 6 & 36 & 12 & 6 & 36 & 20,33 \\
\hline 4 & Kekeruhan & NTU & 65 & 63 & 60 & 52 & 66 & 61 & 52 & 66 & 61,17 \\
\hline 5 & $\mathrm{pH}$ & & 7,0 & 7,3 & 7,0 & 7,1 & 7,2 & 6,9 & 6,9 & 7,3 & 7,08 \\
\hline 6 & BOD-5 & $\mathrm{mg} / \mathrm{L}$ & 1,20 & 1,12 & 1,20 & 1,28 & 1,24 & 1,25 & 1,12 & 1,28 & 1,22 \\
\hline 7 & COD & $\mathrm{mg} / \mathrm{L}$ & 34,32 & 37,94 & 21,08 & 16,26 & 16,26 & 16,26 & 16,26 & 37,94 & 23,69 \\
\hline 8 & DO & $\mathrm{mg} / \mathrm{L}$ & 4,92 & 4,96 & 5,29 & 6,16 & 5,88 & 5,73 & 4,92 & 6,16 & 5,49 \\
\hline 9 & NO3 & $\mathrm{mg} / \mathrm{L}$ & 8,43 & 7,70 & 7,71 & 9,36 & 8,10 & 7,56 & 7,56 & 9,36 & 8,14 \\
\hline 10 & Nitrit & $\mathrm{mg} / \mathrm{L}$ & 0,04 & 0,02 & 0,03 & 0,02 & 0,02 & 0,02 & 0,02 & 0,04 & 0,03 \\
\hline 11 & Sulfat & $\mathrm{mg} / \mathrm{L}$ & 23,88 & 42,33 & 26,32 & 33,95 & 24,19 & 26,78 & 23,88 & 42,33 & 29,58 \\
\hline 12 & Besi & $\mathrm{mg} / \mathrm{L}$ & 0,94 & 0,93 & 0,98 & 0,95 & 1,39 & 0,87 & 0,87 & 1,39 & 1,01 \\
\hline 13 & Klorida & $\mathrm{mg} / \mathrm{L}$ & 3,91 & 3,91 & 3,91 & 3,91 & 3,91 & 3,91 & 3,91 & 3,91 & 3,91 \\
\hline 14 & $\begin{array}{l}\text { Total } \\
\text { Coliform }\end{array}$ & $\begin{array}{c}\mathrm{Jml} / 100 \\
\mathrm{ml}\end{array}$ & 440 & 530 & 440 & 950 & 1500 & 2900 & 440 & 2900 & 1126,67 \\
\hline
\end{tabular}

Sumber : Data Primer 2016

Saluran tersier terdapat paramater yang tidak memenuhi baku mutu baku mutu Kelas I, dan Kelas II. Parameter tersebut adalah COD pada nilai minimum, maksimum dan rata-rata (-10), DO pada nilai minimum dan rata-rata $(-8)$, Besi pada nilai minimum, maksimum dan rata-rata (-10) dan Klorida pada nilai minimum, maksimum dan rata-rata (10). Parameter biologi yaitu total e-colli melebihi batas ambang pada nilai maksimum dan rata-rata $(-12)$. Sehingga total nilai negatif untuk kelas I adalah -50 termasuk pada pencemaran berat.

Tabel 8. Hasil Perhitungan Indeks Storet berdasarkan PP No 82 tahun 2001 pada saluran Tersier di Kecamatan Long Mesangat

\begin{tabular}{cccc}
\hline NO & BAKU MUTU & SALURAN TERSIER & KETERANGAN \\
\hline 1 & Kelas I & -50 & Tercemar Berat \\
2 & Kelas II & -2 & Tercemar Ringan \\
3 & Kelas III & 0 & Memenuhi \\
4 & Kelas IV & 0 & Memenuhi \\
\hline
\end{tabular}

Perhitungan indeks Storet untuk kelas II, saluran sekunder bendung tanah abang tidak memenuhi baku mutu kelas II dengan pencemaran ringan. Parameter yang tidak memenuhi adalah COD hanya pada nilai maksimum (-2), sehingga total skor kelas II adalah -2. Sedangkan untuk kelas III dan IV memenuhi baku mutu.

Secara keseluruhan kualitas saluran primer, sekunder dan tersier termasuk dalam kelas III dan IV. Berdasarkan hasil uji in situ parameter fisika memenuhi standar baku mutu PP no 82 tahun 2001 untuk semua kelas. Parameter suhu pada pengukuran siang hari yang memliki suhu udara $31^{\circ} \mathrm{C}$, suhu air antara $29-32^{\circ} \mathrm{C}$, yang disebabkan kurangnya peneduh di sepanjang saluran irigasi. Suhu tersebut mengalami peningkatan dari hulu ke hilir dan sejalan dengan Jana, dkk., (2014) yang menyatakan bahwa suhu saluran irigasi di 
Subak antara $24-27^{\circ} \mathrm{C}$ dan mengalami kenaikan dari hulu ke hilir meskipun masih memenuhi standar baku mutu.

Parameter kimia berdasarkan uji laboratorium terdapat beberapa parameter yang tidak memenuhi standar baku untuk kelas I dan II yaitu COD, DO dan besi (Fe). Ketiga parameter ini menyebabkan baku mutu untuk kelas I tergolong tercemar berat karena nilai Storet melebihi -30 dan tercemar ringan pada golongan kelas II. Kandungan besi diidentifikasi sebagai penyebab penurunan kualitas air tersebut. Besi yang terdapat daam air akan bereaksi dengan oksigen sehingga kandungan oksigen terlarut berkurang dan kebutuhan oksigen untuk reaksi kimia bertambah. Hal tersebut didukung dengan suhu yang panas sehingga mempercepat reaksi kimia tersebut.

Menurut Putri dan Yudhastuti (2013) sumur masyarakat yang memiliki kandungan besi sebesar 1,694 mg/L mengalami gangguan kesehatan. Masyarakat tersebut terindikasi terpapar besi secara ingesti, hal ini menyebabkan gangguan pencernaan dan gejala lain seperti : badan terasa mudah lelah, mual, muntah, nyeri perut dan diare.

Parameter biologi yaitu total coliform melebihi batas maksimum untuk standar baku mutu kelas I yang peruntukannya untuk air minum. Total coliform merupakan bakteri yang umum berada di lingkungan dan sebagai indikator adanya pencemaran terutama dalam lingkungan perairan. Pada saluran irigasi di Kecamatan Long Mesangat terdapat total coliform yang cukup banyak sehingga air tersebut tidak dapat digunakan untuk air minum. Semakin tinggi tingkat kontaminasi bakteri coliform, semakin tinggi pula risiko kehadiran bakteri-bakteri patogen lain yang biasa hidup dalam kotoran manusia dan hewan. Salah satu contoh bakteri patogen yang kemungkinan terdapat dalam air terkontaminasi kotoran manusia atau hewan berdarah panas ialah bakteri Escherichia coli, yaitu mikroba penyebab gejala diare, demam, kram perut, dan muntah-muntah (Entjang, 2003).

Penggunaan air irigasi terutama pada saluran sekunder untuk keperluan manusia seperti mandi dan cuci masih dilakukan sebagian masyarakat Kecamatan Long Mesangat. Berdasarkan uji kualitas air dinyatakan bahwa air tersebut tercemar berat yaitu logam besi dan total coliform sehingga perlu adanya pengolahan lebih lanjut untuk mengurangi kandungan logam terutama besi dan pemberian disinfektan untuk mengurangi jumlah total coliform.

Kontaminasi produk pertanian dapat terjadi karena kualitas mikroba air. Sumber kontaminasi air dapat berupa bakteri tinja seperti kotoran burung, limpasan air hujan dan kotoran hewan peliharaan (Gerba, dan Rock, 2014). Menurut Partyka, et al.(2016) salmonella dan E. coli dapat berada pada sedimen saluran irigasi. Sedimen yang terpapar pengeringan menunjukkan yang lebih rendah dibandingkan dengan sedimen yang berada di cekungan saluran irigasi yang sama (, 2016). 
Efektifitas disinfektan kaporit dalam penyisihan bakteri Escherichia coli air sumur kawasan Purus dengan dosis kaporit optimum adalah 50 mg/l dengan waktu kontak 30 menit. Efektifitas penyisihan E.coli pada kondisi optimum pada larutan artifisial mencapai $100 \%$ dengan jumlah awal E.coli > 1,6 x $102 \mathrm{sel} / 100 \mathrm{ml}$, sedangkan pada sampel air sumur pada kondisi optimum efisiensi penyisihan 99,9\% dengan jumlah E.coli akhir yaitu 180 sel/100 ml dan sisa klor sebesar 0,4 mg/l (Komala dan Yanarosanti, 2014).

Penurunan kadar besi dalam air dapat dilakukan dengan cara gabungan aerasi dan filtrasi. Aerasi dengan cascade dengan luas $1,8 \mathrm{~m}^{2}$, kemiringan $30^{\circ}$ mampu menurunkan kadar besi 58,36\% dan kadar mangan sebesar 28,05\% (Sutrisno dan Azkiyah, 2014). Febrina dan Ayuna (2015) menambahkan bahwa penggunaan saringan keramik mampu menurunkan kadar besi sebesar 95,20\% dan kadar mangan sebesar 94,63\%. Namun aplikasi penggunaan saringan keramik membutuhkan waktu yang lama.

\section{Analisis Sedimentasi}

Saluran irigasi di Kecamatan Long Mesangat mulai dibangun pada tahun 2010 dengan tujuan untuk mendukung percetakan sawah baru guna meningkatkan ketahanan pangan. Saluran irigasi yang sudah terbangun saat ini tidak terdapat kantong sedimen dan saluran pembilasan. Saluran tersebut terdiri dari saluran primer dengan panjang 2.500 meter, saluran sekunder dengan panjang $12.000 \mathrm{~m}$ dan saluran tersier dengan panjang 38.000 meter. Pada saat ini dibangun kembali saluran irigasi sekunder bagian atas guna mengairi sawah yang berada cukup jauh dari Bendung Tanah Abang.

Kecepatan aliran air diukur dengan menggunakan alat current meter. Hasil pengukuran didapatkan pada saluran primer sebesar $0,3 \mathrm{~m} / \mathrm{s}$, saluran sekunder sebesar $0,4 \mathrm{~m} / \mathrm{s}$ dan saluran tersier adalah $0,1 \mathrm{~m} / \mathrm{s}$. Perkalian kecepatan aliran air dan luas permukaan air menghasilkan debit air dimana pada saluran primer dihasilkan debit sebesar $0,3780 \mathrm{~m}^{3} / \mathrm{s}$. Saluran sekunder memiliki debit sebesar $0,3200 \mathrm{~m}^{3} / \mathrm{s}$ dan saluran tersier sebesar $0,0122 \mathrm{~m}^{3} / \mathrm{s}$.

Tabel 9. Rerata Kecepatan Aliran dan Debit Air di Saluran Irigasi

\begin{tabular}{clcc}
\hline No & Saluran & Kecepatan $(\mathbf{m} / \mathbf{s})$ & Debit $_{\left(\mathbf{m}^{3} / \mathbf{s}\right)}$ \\
\hline 1 & Primer & 0,3 & 0,3780 \\
2 & Sekunder & 0,4 & 0,3200 \\
3 & Tersier & 0,1 & 0,0122 \\
\hline
\end{tabular}

Bentuk bangunan saluran primer adalah trapesium. Luas permukaan air pada saluran primer dengan lebar permukaan $2,50 \mathrm{~m}$, lebar dasar $1,10 \mathrm{~m}$ dan kedalaman 0,70 m memiliki luas sebesar $1,260 \mathrm{~m}^{2}$. Hasil perhitungan laju sedimen pada saluran primer didapatkan nilai tertinggi 1,110 ton/hari dan terendah 0,163 ton/hari. Laju sedimentasi pada saluran primer dipengaruhi jumlah total padatan tersuspensi. Laju sedimentasi tertinggi sebesar 1,110 ton/hari dan nilai terendah adalah 0,163 ton/hari. Air pada saluran primer berasal dari badan sungai. Kecepatan aliran air pada saluran ini dikendalikan oleh sebuah 
ISSN 2354-7251 (print)

pintu air. Semakin besar pintu air yang dibuka maka semakin tinggi kecepatan aliran air pada saluran tersebut.

Tabel 10. Hasil Perhitungan Laju Sedimen pada Saluran Primer

\begin{tabular}{ccccccc}
\hline Sampel & $\begin{array}{c}\text { Luas } \\
\text { Penampang }\end{array}$ & $\begin{array}{c}\text { Kecepatan } \\
\text { Aliran }\end{array}$ & $\begin{array}{c}\text { Total } \\
\text { Suspended } \\
\text { Solid }\end{array}$ & Debit Air & $\begin{array}{c}\text { Faktor } \\
\text { Konversi }\end{array}$ & $\begin{array}{c}\text { Laju } \\
\text { Sedimen }\end{array}$ \\
\hline & $\begin{array}{c}\mathbf{A} \\
\left(\mathbf{m}^{2}\right)\end{array}$ & $\begin{array}{c}\mathbf{V} \\
(\mathbf{m} / \mathbf{s})\end{array}$ & $\begin{array}{c}\mathbf{C} \\
(\mathbf{m g} / \mathbf{L})\end{array}$ & $\begin{array}{c}\mathbf{Q}_{\mathbf{w}}=\mathbf{A . V} \\
(\mathbf{m} / \mathbf{s})\end{array}$ & $\mathbf{k}$ & $\begin{array}{c}\mathbf{Q s}=\mathbf{k} . \mathbf{C .} \mathbf{Q}_{\mathbf{w}} \\
(\mathbf{t o n} / \mathbf{h a r i})\end{array}$ \\
\hline 1 & 1,260 & 0,3 & 32,00 & 0,3780 & 0,0864 & 1,045 \\
2 & 1,260 & 0,3 & 16,00 & 0,3780 & 0,0864 & 0,523 \\
3 & 1,260 & 0,3 & 21,00 & 0,3780 & 0,0864 & 0,686 \\
4 & 1,260 & 0,3 & 34,00 & 0,3780 & 0,0864 & 1,110 \\
5 & 1,260 & 0,3 & 5,00 & 0,3780 & 0,0864 & 0,163 \\
6 & 1,260 & 0,3 & 25,00 & 0,3780 & 0,0864 & 0,816 \\
\hline
\end{tabular}

Saluran sekunder memiliki dimensi yang sama namun kedalaman permukaan air $0,50 \mathrm{~m}$ sehingga luas permukaan sebesar $0,800 \mathrm{~m}^{2}$. Hasil perhitungan laju sedimen pada saluran sekunder disajikan pada Tabel 11.

Tabel 11. Hasil Perhitungan Laju Sedimen pada Saluran Sekunder

\begin{tabular}{|c|c|c|c|c|c|c|}
\hline \multirow[t]{2}{*}{ Sampel } & $\begin{array}{l}\text { Luas } \\
\text { Penampang }\end{array}$ & $\begin{array}{l}\text { Kecepatan } \\
\text { Aliran }\end{array}$ & $\begin{array}{c}\text { Total } \\
\text { Suspended } \\
\text { Solid }\end{array}$ & Debit Air & $\begin{array}{l}\text { Faktor } \\
\text { Konversi }\end{array}$ & $\begin{array}{l}\text { Laju } \\
\text { Sedimen }\end{array}$ \\
\hline & $\underset{\left(m^{2}\right)}{A}$ & $\underset{(m / s)}{V}$ & $\underset{\text { (mg/L) }}{\mathrm{C}}$ & $\begin{array}{c}Q_{w}=A . V \\
\left(m^{3} / s\right)\end{array}$ & k & $\begin{array}{c}\text { Qs = } \\
\text { k.C. } \mathbf{Q}_{w} \\
\text { (ton/hari) }\end{array}$ \\
\hline 1 & 0,800 & 0,4 & 9 & 0,3200 & 0,0864 & 0,249 \\
\hline 2 & 0,800 & 0,4 & 31 & 0,3200 & 0,0864 & 0,857 \\
\hline 3 & 0,800 & 0,4 & 18 & 0,3200 & 0,0864 & 0,498 \\
\hline 4 & 0,800 & 0,4 & 14 & 0,3200 & 0,0864 & 0,387 \\
\hline 5 & 0,800 & 0,4 & 2 & 0,3200 & 0,0864 & 0,055 \\
\hline 6 & 0,800 & 0,4 & 24 & 0,3200 & 0,0864 & 0,664 \\
\hline
\end{tabular}

Laju sedimentasi pada saluran sekunder juga dipengaruhi jumlah total padatan tersuspensi. Laju sedimentasi tertinggi sebesar 0,857 ton/hari dan nilai terendah adalah 0,055 ton/hari. Air pada saluran sekunder berasal dari saluran primer melalui bak pembagi yang dilengkapi dengan pintu air. Saluran primer dibagi menjadi 2 saluran sekunder dengan bukaan yang berbeda.

\section{Saluran Tersier}

Saluran tersier memiliki luas yang lebih kecil dibandingkan saluran primer dan sekunder. Lebar permukaan air sebesar 0,86 $\mathrm{m}$ dan kedalaman 0,18 $\mathrm{m}$ menghasilkan luas permukaan sebesar $0,1224 \mathrm{~m}^{2}$. Pada saluran tersier kecepatan aliran air sebesar $0,1 \mathrm{~m} / \mathrm{s}$, paling kecil dibandingkan saluran lainnya. Kecepatan ini dipengaruhi bukaan pintu air pembagi menuju lahan sawah. Pada saat pengambilan sampel pintu air terbuka sedikit. Sedangkan total padatan tersuspensi relatif sama dengan saluran yang lain. Laju sedimentasi tertinggi sebesar 0,038 ton/hari dan nilai terendah adalah 0,006 ton/hari. Distribusi konsentrasi padatan tersuspensi (TSS) diketahui dengan mengambil sampel pada tiap-tiap saluran yang selanjutnya dianalisa di laboratorium. Rerata TSS yang 
dihasilkan tiap-tiap saluran memiliki nilai terendah adalah $16,33 \mathrm{mg} / \mathrm{L}$ pada saluran sekunder. Nilai rerata TSS tertinggi sebesar $22,17 \mathrm{mg} / \mathrm{L}$ pada saluran primer. Sedangkan pada saluran tersier nilai TSS sebesar $20,33 \mathrm{mg} / \mathrm{L}$. Tabel 13 menunjukkan data sedimentasi pada saluran primer, sekunder dan tersier di Kecamatan Long Mesangat.

Tabel 12. Hasil Perhitungan Laju Sedimen pada Saluran Tersier

\begin{tabular}{|c|c|c|c|c|c|c|}
\hline Sampel & $\begin{array}{c}\text { Luas } \\
\text { Penampang }\end{array}$ & $\begin{array}{c}\text { Kecepatan } \\
\text { Aliran }\end{array}$ & $\begin{array}{c}\text { Total } \\
\text { Suspended } \\
\text { Solid }\end{array}$ & Debit Air & $\begin{array}{l}\text { Faktor } \\
\text { Konversi }\end{array}$ & $\begin{array}{c}\text { Laju } \\
\text { Sedimen }\end{array}$ \\
\hline & $\begin{array}{c}A \\
\left(m^{2}\right)\end{array}$ & $\begin{array}{c}V \\
(m / s)\end{array}$ & $\begin{array}{c}\mathbf{C} \\
(\mathrm{mg} / \mathrm{L})\end{array}$ & $\begin{array}{c}Q_{w}=A . V \\
\left(m^{3} / s\right)\end{array}$ & k & $\begin{array}{c}\text { Qs = k.C.Q }{ }_{w} \\
\text { (ton/hari) }\end{array}$ \\
\hline 1 & 0,1224 & 0,1 & 18 & 0,0122 & 0,0864 & 0,019 \\
\hline 2 & 0,1224 & 0,1 & 20 & 0,0122 & 0,0864 & 0,021 \\
\hline 3 & 0,1224 & 0,1 & 30 & 0,0122 & 0,0864 & 0,032 \\
\hline 4 & 0,1224 & 0,1 & 6 & 0,0122 & 0,0864 & 0,006 \\
\hline 5 & 0,1224 & 0,1 & 36 & 0,0122 & 0,0864 & 0,038 \\
\hline 6 & 0,1224 & 0,1 & 12 & 0,0122 & 0,0864 & 0,013 \\
\hline
\end{tabular}

Tabel 13. Rerata Sedimentasi Saluran Irigasi di Kecamatan Long Mesangat

\begin{tabular}{lcccccc}
\hline Saluran & $\begin{array}{c}\text { Luas } \\
\text { Penampang }\end{array}$ & $\begin{array}{c}\text { Kecepatan } \\
\text { Aliran }\end{array}$ & $\begin{array}{c}\text { Total } \\
\text { Suspended } \\
\text { Solid }\end{array}$ & Debit Air & $\begin{array}{c}\text { Faktor } \\
\text { Konversi }\end{array}$ & $\begin{array}{c}\text { Laju } \\
\text { Sedimen }\end{array}$ \\
\cline { 2 - 7 } & $\begin{array}{c}\mathbf{A} \\
\left(\mathbf{m}^{2}\right)\end{array}$ & $\begin{array}{c}\mathbf{V} \\
(\mathbf{m} / \mathbf{s})\end{array}$ & $\begin{array}{c}\mathbf{C} \\
(\mathbf{m g} / \mathbf{L})\end{array}$ & $\begin{array}{c}\mathbf{Q}_{\mathbf{w}}=\mathbf{A . V} \\
(\mathbf{m} \mathbf{m} / \mathbf{s})\end{array}$ & $\mathbf{k}$ & $\begin{array}{c}\mathbf{Q s}= \\
\mathbf{k} . \mathbf{C .} \mathbf{Q}_{\mathbf{w}} \\
(\text { ton/hari })\end{array}$ \\
\hline Primer & 1,260 & 0,3 & 22,17 & 0,3780 & 0,0864 & 0,724 \\
Sekunder & 0,800 & 0,4 & 16,33 & 0,3200 & 0,0864 & 0,451 \\
Tersier & 0,1224 & 0,1 & 20,33 & 0,0122 & 0,0864 & 0,021 \\
\hline
\end{tabular}

Laju sedimentasi merupakan perkalian konstanta sedimen dengan debit air dan faktor konversi $(0,0864)$. Laju sedimen pada saluran primer merupakan nilai tertinggi yaitu sebesar 0,724 ton/hari, selanjutnya saluran sekunder sebesar 0,451 ton/hari dan terendah pada saluran tersier yaitu sebesar 0,021 ton/hari.

Penurunan laju sedimen dapat disebabkan adanya pengendapan sepanjang saluran air. Selain itu juga dipengaruhi kecepatan aliran semakin turun kecepatan aliran maka laju sedimen juga berkurang. Penurunan laju sedimen saluran irigasi sejalan dengan penelitian Suleman (2015) Dengan menggunakan metode pengukuran sesaat diperoleh volume sedimen melayang (suspended load) pada tiap-tiap saluran mengalami penurunan yaitu pada Saluran Primer Sanrego sebesar 4,253 kg/hari, Saluran Sekunder Palakka sebesar 1,218 kg/hari dan Saluran Sekunder Batu - Batu sebesar 0,0593 kg/hari.

Menurut Ochiere et al., (2015) bahwa persamaan transportasi sedimen Ackers-White memperkirakan ukuran sedimen yang diendapkan pada bagian tertentu dari kanal dengan laju aliran yang berbeda. Laju aliran yang lebih tinggi menghasilkan pengendapan yang minimal. Dan untuk meminimalkan sedimentasi digunakan saringan pada awal saluran intake. Sehingga sedimen yang lolos saringan akan keluar tanpa diendapkan.

Laju sedimentasi pada saluran irigasi di Kecamatan Long Mesangat dari saluran primer sampai dengan saluran tersier mengalami penurunan yaitu 0,724 ton/hari, 0,451 ton/hari dan 0,021 ton/hari. Penurunan laju sedimentasi menunjukan bahwa telah terjadi 
pengendapan pada tiap-tiap saluran. Pengendapan yang terus-menerus dan dalam jangka waktu yang lama akan menyebabkan terjadinya pendangkalan saluran sehingga fungsi saluran tidak optimal. Masuknya padatan ini disebabkan adanya erosi yang terjadi di daerah sekitar aliran sungai. Pada musim kemarau erosi yang terjadi cukup kecil dikarenakan air hujan sebagai faktor pengangkut tidak ada.

Menurut Susetyaningsih dan Permana (2016) Daerah Irigasi Cimanuk memiliki debit sedimen yang terjadi adalah sebesar $0,00088 \mathrm{~m} 3 / \mathrm{det}(0,88 \mathrm{lt} / \mathrm{det})$. Dengan asumsi tebal sedimen yang mengendap di dasar saluran $1 \mathrm{~cm}$, dan lebar saluran $1 \mathrm{~m}$ didapat panjang sedimen yang mengendap adalah sepanjang 0,088 m. pengendapan ini menjadikan penampang saluran berkurang dan akan mempengaruhi debit air yang harus dialirkandi saluran-saluran irigasi berikutnya.

Saluran primer memiliki laju sedimen yang tinggi dibandingkan dengan saluran yang lainnya. Saluran primer menerima air secara langsung dari sungai sehingga kandungan padatan tersuspensi, kadar logam dan kandungan mikroorganisme relatif sama dengan air sungai. Pada saluran primer di Kecamatan Long Mesangat tidak terdapat bangunan penangkap lumpur dan saluran pembilasan. Bangunan ini sangat penting untuk mengurangi laju sedimen di saluran irigasi. Dengan tidak adanya bangunan ini padatan tersuspensi akan langsung terbawa aliran menuju hilir yang kecepatan aliran semakin rendah sehingga terjadi pengendapan.

\section{Kesimpulan}

Kualitas air pada saluran irigasi di Kecamatan Long Mesangat memenuhi standar baku mutu kelas III dan IV yang peruntukannya adalah budidaya perikanan dan pertanian. Kualitas air secara fisika dalam kondisi yang memenuhi standar baku mutu, sedangkan secara kimia dan biologi tidak memenuhi baku mutu kelas I dan II. Pencemaran yang terjadi banyak disebabkan aktifitas pertanian seperti penggunaan pestisita, pupuk yang berlebih dan juga adanya pembusukan bahan-bahan organik. Sedangkan pencemaran biologi yaitu parameter total coliform banyak disebabkan oleh kotoran hewan. Laju sedimentasi pada saluran primer, sekunder dan tersier berturut-turut adalah 0,724 ton/hari, 0,451 ton/hari dan 0,021 ton/hari. Hal ini dipengaruhi adanya pencetakan dan pembukaan lahan baru. Untuk mengurangi laju sedimentasi perlu dilakukan perbanyakan tanaman di sepanjang daerah aliran sungai dan juga pembangunan saluran bilas pada Bendung Tanah Abang untuk menahan padatan terlarut masuk ke dalam saluran primer.

\section{Daftar Pustaka}

Astuti, A. D. (2014). Kualitas Air Irigasi Ditinjau Dari Parameter DHL, TDS, pH pada Lahan Sawah Desa Bulumanis Kidul Kecamatan Margoyoso. Jurnal Litbang: Media Informasi Penelitian, Pengembangan dan IPTEK, 10(1): 35-42. 
Atima, W. (2015). BOD dan COD Sebagai Parameter Pencemaran Air Dan Baku Mutu Air Limbah. Biosel (Biology Science and Education): Jurnal Penelitian Sains dan Pendidikan, 4(1): 83-93.

Azmi Luftan A.U., Dermawan Very, Suhardjono. (2015). Analisa Nilai Sebaran Oksigen Terlarut Pada Bangunan Pintu Air Di Saluran Irigasi Kepanjen Dan Tumpang Kabupaten Malang. Diakses 8 Mei 2016 dari http://pengairan.ub.ac.id/wpcontent/uploads/2016/01/Analisa-Nilai-Sebaran-Oksigen-Terlarut-pada-BangunanPintu-Air-di-Saluran-Irigasi-Kepanjen-dan-Tumpang-Kabupaten-Malang-LuftanAlses-U.A-105060400111038.pdf.

Effendi H. (2003). Telaah Kualitas Air, Bagi Pengelolaan Sumber Daya dan Lingkungan Perairan. Yogyakarta: Kanisius.

Entjang, I. (2003). Mikrobiologi dan Parasitologi untuk Akademi Keperawatan dan Sekolah Tenaga Kesehatan yang Sederajat. Bandung: Citra Adtya Bakti

Febrina L dan A. Astrid .(2015). Studi Penurunan Kadar Besi (Fe) Dan Mangan (Mn) Dalam Air Tanah Menggunakan Saringan Keramik. Jurnal Teknologi Universitas Muhammadiyah Jakarta 7(1): 35-44

Gerba, C. P., \& Rock, C. (2014). Water quality. In The produce contamination problem. Academic Press.

Kementrian Dalam Negeri. (2015). Kondisi Saluran Irigasi Kabupaten Kutai Timur Kalimantan Timur. Jakarta. Direktorat Jenderal Pemberdayaan Masayarakat dan $\begin{array}{lllll}\text { Desa. } & \text { Diakses } & 9 & \text { Februari } & 2016\end{array}$ http://prodeskel.binapemdes.kemendagri.go.id/mpublik.

Komala P. S. \& Y. Ajeng. (2014). Inaktivasi Bakteri Escherichia coli Air Sumur Menggunakan Disinfektan Kaporit. Jurnal Dampak 11(1): 34-47

Ochiere, H. O., Onyando, J. O., \& Kamau, D. N. (2015). Simulation Of Sediment Transport In The Canal Using The Hec-Ras (Hydrologic Engineering Centre-River Analysis System) in An Underground Canal in Southwest Kano Irrigation SchemeKenya. International Journal of Engineering Science Invention, 4(9):15-31.

Partyka, M. L., Bond, R. F., Chase, J. A., Kiger, L., \& Atwill, E. R. (2016). Multistate evaluation of microbial water and sediment quality from agricultural recovery basins. Journal of environmental quality, 45(2): 657-665.

Putri,T. A. \& Yudhastuti, R. (2013). Kandungan Besi (Fe) Pada Air Sumur Dan Gangguan Kesehatan Masyarakat Di Sepanjang Sungai Porong Desa Tambak Kalisogo Kecamatan Jabon Sidoarjo. Jurnal Kesehatan Lingkungan 7(1): 64-70

Suleman, A. R. (2015). Analisis Laju Sedimentasi Pada Saluran Irigasi Daerah Irigasi Sanrego Kecamatan Kahu Kabupaten Bone Provinsi Sulawesi Selatan. Jurnal Wahana Teknik Sipil 20(2):76-86

Susetyaningsih, A., \& Permana, S. (2016). Pengaruh Sedimentasi Terhadap Penyaluran Debit Pada Daerah Irigasi Cimanuk. Jurnal Konstruksi, 14(1): 149-153

Sutrisno, J. \& Azkiyah I. N.F. (2014). Penurunan Kadar Besi (Fe) dan Mangan (Mn) pada Air Sumur Gali Dengan Menggunakan Metode Aerasi dan Filtrasi di Sukodono Sidoarjo. Waktu : Jurnal Teknik Unipa, 12(2): 28-33

Vymazal, J., \& Březinová, T. (2015). The use of constructed wetlands for removal of pesticides from agricultural runoff and drainage, a review. Environment international, 75:11-20. 